\title{
Mycophenolic Acid Production by Drug-resistant and Methionine or Glutamic-Acid Requiring Mutants of Penicillium brevicompactum
}

\author{
Hachiro OzaKi, Masaru IsHIHARA, Takao KIDA, \\ Shigeru Yamanaka and Hiroshiro SHibaI \\ Central Research Laboratories, Ajinomoto Co., Inc., \\ Kawasaki-ku, Kawasaki, Kanagawa 210, Japan
}

Received April 22, 1987

\begin{abstract}
Penicillium brevicompactum ATCC 16024 produced $1.7 \mathrm{~g} / 1$ of mycophenolic acid (MPA) in the culture medium. Various drug-resistant mutants, showing resistance to such as polyene antibiotics, chemotherapeutic agents, redox indicator and surfactants, were derived from the fungus. Most of the mutants produced $2.0 \sim 2.5 \mathrm{~g} / \mathrm{l}$ of MPA. A clofibrate and dodecyltrimethylammonium chloride double resistant mutant, No. 4-23-11, produced $4.7 \mathrm{~g} / 1$ of MPA. A monofluoroacetic acid resistant strain, No. 5-1, derived from No. 4-23-11 produced 5.3 g/l of MPA.

A methionine auxotroph, M-1, derived from ATCC 16024, produced $4.0 \mathrm{~g} / 1$ of MPA. A glutamate auxotroph, G-42, derived from strain No. 4-23-11 produced 5.8 g/l of MPA. G-42 grew on L-aspartate instead of L-glutamate, and showed one-third the pyruvate carboxylase activity of the parent. Another glutamate auxotroph, G-78, did not produce MPA but accumulated $1.5 \mathrm{~g} / \mathrm{l}$ of acetate in the culture medium, and showed one-fifth the citrate synthase activity of the parent strain.
\end{abstract}

Mycophenolic acid (MPA) is a metabolite produced by several species of Penicillium, including $P$. brevicompactum and $P$. stoloniferum. ${ }^{1)}$ MPA has been reported to exhibit biological activity against fungi, bacteria, tumors, viruses and psoriasis. ${ }^{1)}$ A biosynthetic pathway for MPA was proposed by Birch. ${ }^{2)}$ Both the phenolic nucleus and the sevenmembered sidechain of MPA are formed from acetate units. Breeding of a MPA producer was reported by Queener et al. with polyene antibiotic-resistant mutants of $P$. stoloniferum. ${ }^{3)}$ But no other breeding study has been reported.

This paper deals with production of MPA by various drug-resistant and methionine or glutamate auxotrophic mutants of $P$. brevicompactum.

\section{MATERIALS AND METHODS}

Microbial strain and culture medium. Penicillium brevi- compactum ATCC 16024 was used as the original strain. Medium 1 was composed of $10 \mathrm{~g}$ of glucose, $2 \mathrm{~g}$ of peptone, $1 \mathrm{~g}$ of malt extract, $1 \mathrm{~g}$ of yeast extract and $20 \mathrm{~g}$ of agar in final volume of $11(\mathrm{pH} \mathrm{6.5)}$, and was sterilized at $120^{\circ} \mathrm{C}$ for $15 \mathrm{~min}$. Medium 2 was composed of $30 \mathrm{~g}$ of glucose, $3 \mathrm{~g}$ of $\mathrm{NaNO}_{3}, 1 \mathrm{~g}$ of $\mathrm{KH}_{2} \mathrm{PO}_{4}, 0.5 \mathrm{~g}$ of $\mathrm{KCl}, 0.01 \mathrm{~g}$ of $\mathrm{FeSO}_{4} \cdot 7 \mathrm{H}_{2} \mathrm{O}$ and $15 \mathrm{~g}$ of agar in a final volume of one liter ( $\mathrm{pH} \mathrm{6.8)}$, and was sterilized at $120^{\circ} \mathrm{C}$ for $15 \mathrm{~min}$. Medium 3 was composed of $100 \mathrm{~g}$ of glucose, $14 \mathrm{~g}$ of glycine, $0.5 \mathrm{~g}$ of L-methionine, $3 \mathrm{~g}$ of $\mathrm{KH}_{2} \mathrm{PO}_{4}, 1 \mathrm{~g}$ of $\mathrm{MgSO}_{4}$. $7 \mathrm{H}_{2} \mathrm{O}$ and $1 \mathrm{ml}$ of a trace element mixture, containing $0.22 \% \quad \mathrm{FeSO}_{4} \cdot 7 \mathrm{H}_{2} \mathrm{O}, \quad 0.03 \% \quad \mathrm{CuSO}_{4} \cdot 5 \mathrm{H}_{2} \mathrm{O}, \quad 0.246 \%$ $\mathrm{ZnSO}_{4} \cdot 7 \mathrm{H}_{2} \mathrm{O}, 0.016 \% \mathrm{MnSO}_{4} \cdot 4 \mathrm{H}_{2} \mathrm{O}$ and $0.02 \% \mathrm{KMoO}_{4}$ (pH 4.5), in a final volume of 11 . Medium 3 without glycine and methionine, and the glycine-methionine mixture were separately sterilized at $120^{\circ} \mathrm{C}$ for $10 \mathrm{~min}$.

Production of MPA. The fugus was cultured in medium 1 at $26^{\circ} \mathrm{C}$ for $7 \sim 10$ days. The spores were inoculated into a test tube or a $300 \mathrm{ml}$ Ehlenmeyer flask containing $5 \mathrm{ml}$ or $50 \mathrm{ml}$ of medium 3 , respectively, to give a final concentration of $10^{4} \sim 10^{7} / \mathrm{ml}$. The test tube was allowed to stand and the flask was shaken on a shaker at $226 \mathrm{rpm}$ at $26^{\circ} \mathrm{C}$ for $14 \sim 15$ days. In order to obtain reproducible production of MPA, celite, previously sterilized, was added to the flask to a final concentration of $1 \%$, which led

Abbreviations: MPA, mycophenolic acid; MV, methylviologen; SDBS, sodium dodecylbenzenesulfonate; DTAC, dodecyltrimethylammonium chloride; MFA, monofluoroacetic acid. 
to the formation of small pellets of mycelium. ${ }^{4)}$

Measurement of MPA and growth. After cultivation, the broth was adjusted to $\mathrm{pH} 10 \sim 11$, shaken at $30^{\circ} \mathrm{C}$ for $20 \mathrm{~min}$ and then filtered through a preweighed filter paper. The filtrate was centrifuged at $10,000 \mathrm{rpm}$ for $10 \mathrm{~min}$. MPA in the supernatant was assayed by HPLC on a cation exchange resin column (Zipax SCX, $2.6 \times 500 \mathrm{~mm}$, at $45^{\circ} \mathrm{C}$ ) in $0.1 \mathrm{M}$ potassium phosphate buffer, $\mathrm{pH} 6.0$, by measuring the absorbance at $254 \mathrm{~nm}$. Purified MPA was used as a standard.

The mycelium fraction on a preweighed filter paper was washed with water, dried at $105^{\circ} \mathrm{C}$ overnight and then weighed. The weight of the mycelium was used to express growth.

Derivation of drug-resistant and methionine or glutamate auxotrophic mutants. The spores on mycelium grown on medium 1 were suspended in $0.1 \mathrm{M}$ potassium phosphate buffer, $\mathrm{pH} 7.0$, washed twice with the buffer and then filtered through a glass filter $3 \mathrm{G}$ to remove mycelium. $N$ Methyl- $N^{\prime}$-nitro- $N$-nitrosoguanidine was added to the spore suspension to a final concentration of $500 \mu \mathrm{g} / \mathrm{ml}$, followed by incubation at $26^{\circ} \mathrm{C}$ for $20 \mathrm{~min}$. The treated spores were washed and suspended in the buffer. For selection of drug-resistant mutants, spore suspension (about $10^{5}$ ) was spread on a plate of medium 1 , followed by incubation at $26^{\circ} \mathrm{C}$ for $5 \sim 10$ days. Colonies which appeared on medium 1 containing a drug were picked up and then subjected to re-examination for the resistance.

For derivation of methionine or glutamate auxotrophs, spore suspension containing $50 \sim 100$ spores was spread on a plate of medium 1 supplemented with $0.1 \% \mathrm{~L}$-methionine or $1 \%$ monosodium L-glutamate, followed by incubation at $26^{\circ} \mathrm{C}$ for $3 \sim 4$ days. The colonies on the medium were replicated onto medium 2 and the medium supplemented with $0.1 \%$ L-methionine or $1 \%$ L-glutamate. Colonies which grew on the latter but not on the former were picked up and re-examined for the amino acid requirement.

Preparation of crude extracts. The fungus was cultured at $26^{\circ} \mathrm{C}$ for 6 days on rotary shaker in a $300 \mathrm{ml}$ Ehlenmeyer flask containing $50 \mathrm{ml}$ of medium 3 . Glutamate auxotrophs were cultured in medium 3 supplemented with $1 \%$ sodium glutamate. The mycelium ( $1.5 \mathrm{~g}$ as dry cell weight) was collected by filtration, washed with $0.2 \% \mathrm{KCl}$, suspended in $16 \mathrm{ml}$ of $0.1 \mathrm{M} \mathrm{N}$-Tris(hydroxyl)methyl-2-aminoethane sulfonic acid (TES)$\mathrm{NaOH}$ buffer, pH 7.5, containing $30 \%$ glycerol, $5 \mathrm{~mm}$ $\mathrm{MgCl}_{2}$ and $1 \mathrm{M}\left(\mathrm{NH}_{4}\right)_{2} \mathrm{SO}_{4}$ (buffer $\mathrm{A}$ ), and then ruptured in a sonic oscillator for $10 \mathrm{~min}$ below $10^{\circ} \mathrm{C}$. The mycelial debris was removed by centrifugation at $20000 \times$ $g$ for $30 \mathrm{~min}$. The supernatant was gel-filtered through a Sephadex G-50 column using buffer A.

Enzyme assay. Enzyme activities were determined by measuring the initial rates of the reactions with a Gilford spectrophotometer at room temperature $\left(20 \sim 23^{\circ} \mathrm{C}\right)$, after the reactions had been started by the addition of the enzyme. Pyruvate carboxylase was assayed by a modification of the method of Scrutton et al. ${ }^{5)}$ The reaction mixture was composed of $0.1 \mathrm{M}$ Tris- $\mathrm{HCl}$ buffer, $\mathrm{pH} 7.4$, $2 \mathrm{~mm} \mathrm{MgCl}_{2}, 0.15 \mathrm{~mm} \mathrm{NADH}, 10 \mathrm{~mm} \mathrm{NaHCO}_{3}, 2 \mathrm{~mm}$ pyruvate, $0.5 \mathrm{~mm}$ ATP, $0.1 \mathrm{~mm}$ acetyl CoA, malate dehydrogenase and enzyme in a final volume of $1 \mathrm{ml}$. One unit of the enzyme activity was defined as the amount of enzyme converting 1 nmol NADH to NAD per min.

Citrate synthase activity was assayed by the method of Srere et al. $\left.{ }^{6}\right)$ The reaction mixture was composed of $0.05 \mathrm{M}$ Tris- $\mathrm{HCl}$ buffer, $\mathrm{pH} 8.0,1 \mathrm{~mm}$ oxalacetate, $0.1 \mathrm{~mm}$ actylCoA, $0.1 \mathrm{~mm}$ DTNB and enzyme in 11 . The initial rate of the absorbance increase at $412 \mathrm{~nm}$ was recorded. One unit of the enzyme was defined as the amount producing $1 \mathrm{nmol} \mathrm{CoA}$ per min.

Chemicals. Mycophenolic acid was a product of Ajinomoto Co. Amphotericin B, nystatin, kabicidin, clofibrate and cerulenin were purchased from Wako Chemical Industries, Ltd. Methyviologen, monofluoroacetic acid, sodium dodecylbenzenesulfonate and dodecyltrimethylammonium chloride were products of Tokyo Kasei Kogyo Co., Ltd. Pimaricin was purchased from Sigma Chem. Co.

\section{RESULTS}

\section{Derivation of drug-resistant mutants}

$P$. brevicompactum ATCC 16024 accumulated $1.7 \mathrm{~g} / 1$ of MPA in the culture medium and showed sensitivity to the various drugs in Table I. Various mutants resistant to these drugs were derived from the fungus, and their MPA productivities were examined. The results are shown in Table I. Amphotericin B, pimaricin, clofibrate, cerulenin, methylviologen (MV), sodium dodecylbenzenesulfonate (SDBS) and dodecyltrimethylammonium chloride (DTAC) resistant mutants produced $2.2,2.3,2.5,2.1,2.1,2.5$ or $2.2 \mathrm{~g} / 1$ of MPA, respectively. Double resistant mutants to clofibrate plus MV (No. 4-266), clofibrate plus SDBS (No. 4-808), and clofibrate plus DTAC (No. 4-23) derived from clofibrate resistant strain No. 2-216 produced 3.4, 3.4 and $3.6 \mathrm{~g} / \mathrm{l}$ of MPA, respectively, as shown in Table II. A reisolated strain, No. 4-23-11, among the colonies of No. 4-23 produced $4.7 \mathrm{~g} / 1$ of MPA. A monofluoroacetic acid (M.FA) resistant strain, No. 5-1, derived from No. 4-23-11 pro- 
Table I. Production of MPA by Various DrugResistant Mutants of Penicillium brevicompactum

\begin{tabular}{clc}
\hline Strain No. & \multicolumn{1}{c}{$\begin{array}{c}\text { Resistant } \\
\text { to } \\
(\mu \mathrm{g} / \mathrm{ml})^{*}\end{array}$} & $\begin{array}{c}\text { MPA } \\
\text { production } \\
(\mathrm{g} / \mathrm{l})\end{array}$ \\
\hline ATCC 16024 & (Parent) & 1.7 \\
$1-45$ & Amphotericin B (100) & 2.2 \\
$2-22$ & Pimaricin (10) & 2.3 \\
$2-56$ & Nystatin (10) & 1.8 \\
$2-46$ & Kabicidin (5) & 1.0 \\
$2-216$ & Clofibrate (500) & 2.5 \\
$3-530$ & Cerulenin (125) & 2.1 \\
$3-214$ & Methylviologen (100) & 2.1 \\
$3-148$ & SDBS (250) & 2.5 \\
$3-677$ & DTAC (25) & 2.4 \\
\hline
\end{tabular}

* Concentrations at which mutants were obtained. SDBS, sodium dodecylbenzene sulfonate; DTAC, dodecyltrimenthylammonium chloride.

Table II. Production of MPA by Multiple Resistant Mutants

\begin{tabular}{llc}
\hline Strain No. & \multicolumn{1}{c}{$\begin{array}{c}\text { Resistant } \\
\text { to } \\
(\mu \mathrm{g} / \mathrm{ml}) *\end{array}$} & $\begin{array}{c}\text { MPA } \\
\text { production } \\
(\mathrm{g} / \mathrm{l})\end{array}$ \\
\hline 2-216 (Parent) & Clofibrate (500) & 2.5 \\
$4-23$ & Clofibrate (500), DTAC (50) & 3.6 \\
$4-808$ & Clofibrate (500), SDBS (500) & 3.5 \\
$4-266$ & Clofibrate (500), MV (125) & 3.4 \\
$4-23-11^{* *}$ & Clofibrate (500), DTAC (50) & 4.7 \\
$5-1$ & Clofibrate (500), DTAC (50), & \\
& MFA (5000) & 5.3
\end{tabular}

* Concentrations at which mutants were obtained.

** A strain isolated from among the colonies of No. 423-11.

duced $5.3 \mathrm{~g} / 1$ of MPA, as shown in Table II.

Derivation of methionine and glutamate auxotrophs

When one of 18 L-amino acids and 7 Damino acids were added to medium 3 to a final concentration of $0.5 \%$, L-methionine inhibited $40 \%$ of the MPA production by ATCC 16024. So an attempt was made to derive a $\mathrm{L}$ methionine auxotroph from the original strain. A methionine auxotroph, M-1, was obtained, and its MPA production was examined in the presence of various concentrations of $\mathrm{L}$ -

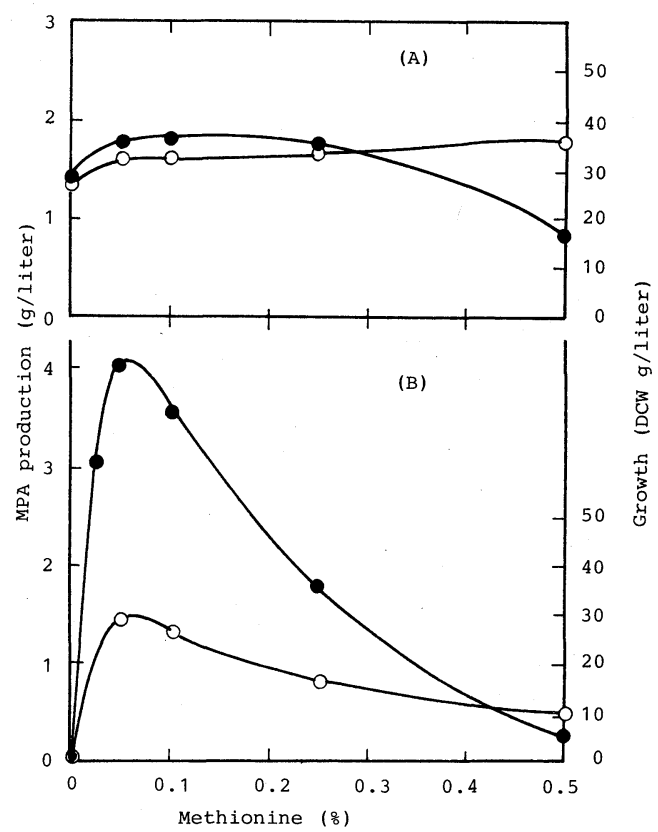

FIG. 1. Effects of the L-Methionine Concentration on Growth and MPA Production by Methionine Auxotroph M-1.

Strain ATCC 16024 (A) and M-1 (B) were cultured in medium 3 containing the indicated concentrations of $\mathrm{L}-$ methionine for 10 days. (O), MPA production; ( $\bigcirc)$, growth.

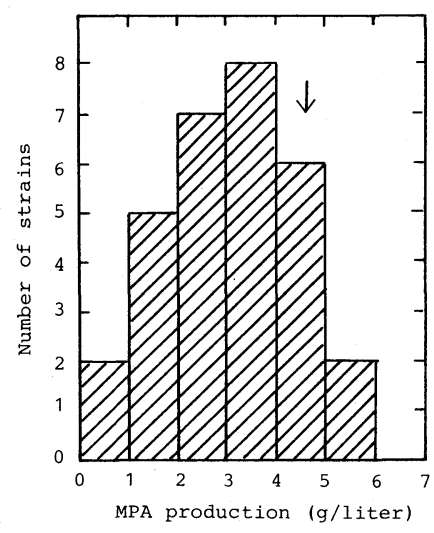

FIG. 2. Distribution of MPA Productivities of LGlutamate Auxotrophs.

The arrow indicates the amount of MPA produced by the parent, No. 4-23-11.

methionine. The results are shown in Fig. 1. It showed the maximum MPA production of $4.0 \mathrm{~g} / 1$.

Glutamate auxotrophic mutants were de- 
Table III. Production of MPA by Glutamate Auxotrophs

Sodium L-glutamate was added to medium 3 to a final concentration of $1 \mathrm{~g} / \mathrm{l}$.

\begin{tabular}{|c|c|c|c|c|c|}
\hline \multirow{2}{*}{ Strain No. } & \multicolumn{3}{|c|}{ Growth (6 days) } & \multirow{2}{*}{$\begin{array}{c}\text { MPA } \\
\text { production } \\
(\mathrm{g} / \mathrm{l})\end{array}$} & \multirow{2}{*}{$\begin{array}{c}\text { Acetate } \\
\text { accumulated } \\
(\mathrm{g} / \mathrm{l})\end{array}$} \\
\hline & MM & $\mathrm{MM}+\mathrm{Glu}$ & $\mathrm{MM}+\mathrm{Asp}$ & & \\
\hline $4-23-11$ & +++ & +++ & +++ & $4.0 * 4.7$ & 0.2 \\
\hline $\mathrm{G}-3$ & + & +++ & + & 2.0 & 0.4 \\
\hline G-9 & - & +++ & + & 5.1 & 0.4 \\
\hline G-27 & + & +++ & + & 3.9 & ( ) \\
\hline G-42 & + & $++t$ & +++ & 5.8 & 0.5 \\
\hline G-45 & + & +++ & +++ & 3.9 & ( ) \\
\hline G-50 & + & ++ & ++ & 4.2 & ( ) \\
\hline G-53 & - & ++ & ++ & 0.45 & ( ) \\
\hline G-78 & - & +++ & + & 0.24 & 1.5 \\
\hline G- 88 & - & +++ & + & 3.8 & ( ) \\
\hline G-105 & - & +++ & +++ & 2.3 & () \\
\hline
\end{tabular}

* No glutamate was added.

( ): Not determined.

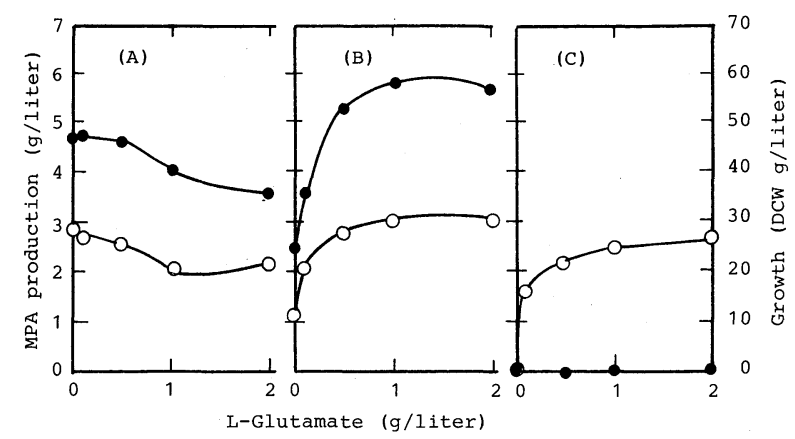

FIG. 3. Effects of the L-Glutamate Concentration on Growth and MPA Production by L-Glutamate Auxotrophs.

Strain Nos. 4-23-11 (A), G-42 (B) and G-78 (C) were cultured in medium 3 supplemented with the indicated concentrations of sodium $\mathrm{L}$-glutamate for 10 days. (O

), MPA production; (O), growth.

rived from strain No. 4-23-11. Figure 2 shows the distribution of the MPA productivities of 29 glutamate auxotrophic strains. Among them two auxotrophs, G-9 and G-42, produced 5.1 and $5.8 \mathrm{~g} / 1$ of MPA, respectively, as shown in Table III. G-42 was found to require either L-glutamate or L-aspartate, while G-9 strictly required L-glutamate. C-53 and G-78 accumulated MPA only slightly. G-42, G-78 and the parent, No. 4-23-11, were cultured in the presence of various concentrations of $\mathrm{L}$ glutamate. The results are shown in Fig. 3. G42 showed the maximum production of MPA of $5.8 \mathrm{~g} / 1$ in the presence of $1 \sim 2 \mathrm{~g} / 1$ of $\mathrm{L}$ - glutamate, while the parent showed a slight decrease in MPA production in the presence of the amino acid. G-78 did not accumulate MPA in the presence of $0 \sim 2 \mathrm{~g} / \mathrm{l}$ of L-glutamate.

As G-78 did not accumulate MPA, acetic acid, one of the intermediates of MPA biosynthesis, in the culture supernatant was assayed. G-78 was found to accumulate $1.5 \mathrm{~g} / \mathrm{l}$ of acetic acid, while the parent and MPA-producing glutamate auxotrophs accumulated it only slightly $(0.2 \sim 0.5 \mathrm{~g} / 1)$.

\section{Enzyme activities of glutamate auxotrophs}

Citrate synthase and pyruvate carboxylase 
Table IV. Pyruvate Carboxylase and Citrate Synthase Activities

\begin{tabular}{|c|c|c|}
\hline \multirow{2}{*}{ Strain No. } & \multicolumn{2}{|c|}{$\begin{array}{c}\text { Enzyme activity } \\
\text { (units/ml/mg protein) }\end{array}$} \\
\hline & $\begin{array}{c}\text { Pyruvate } \\
\text { carboxylase }\end{array}$ & $\begin{array}{l}\text { Citrate } \\
\text { synthase }\end{array}$ \\
\hline $4-23-11$ & 4.5 & 45.5 \\
\hline G-9 & 4.8 & 47.0 \\
\hline G-42 & 1.7 & 46.2 \\
\hline G-78 & 3.7 & 10.1 \\
\hline
\end{tabular}

activities of the parent and glutamate auxotrophs were determined. The results are shown in Table IV. G-78 showed one-fifth the citrate synthase activity of the parent, and G-42 showed one-third the pyruvate carboxylase activity of the parent. G-9 showed the same activities of both enzymes as the parent.

\section{DISCUSSION}

Among the four mutants which were resistant to polyene antibiotics, amphotericin B resistant (No. 1-45) and pimaricin resistant (No.2-22) mutants showed 1.3 1.4-fold MPA production compared to the parent, No. 16024. A nystatin resistant mutant (No. 2-56) showed nearly the same productivity as the parent, and a kabicidin resistant mutant (No. 2-46) showed lower productivity than the parent. Similar results have been reported for P. stoloniferum, i.e., various levels of MPA production were observed among polyeneantibiotic-resistant mutants. ${ }^{3)}$ This is, however, the first case of mutants, which were resistant to drugs other than polyene-antibiotics, showing significant increases in the MPA production.

The mutation sites of these mutants have not been determined. Clofibrate and cerulenin are known as inhibitors of hydroxymethylglutaryl (HMG)-CoA reductase ${ }^{7)}$ and HMG-CoA synthase, ${ }^{8)}$ respectively, both of which are located in the biosynthetic pathway for the seven-membered sidechain of MPA. Therefore, it is reasonable to speculate that the mech- anism by which these mutants obtain resistance to both compounds may be reflected by increases in the enzyme levels or changes of the enzyme property to a non-inhibitory form. The mechanism by which mutant Nos. 3-214, 3-148 and 3-677 obtain resistance to methylviologen, SDBS and DTAC, respectively, may be the result of mutation of the cell membrane, which became more permeable to MPA.

It is generally known that monofluoroacetic acid inhibits aconitase through the formation of monofluorocitrate. Therefore, it might be supposed that the increase in MPA production by MFA-resistant strain No. 5-1 is the result of an increase in the ATP level in the cells due to an increase in TCA-cycle activity. Glutamate (or aspartate) auxotroph G-42 showed increase MPA production and one-third the pyruvate carboxylase activity of the parent. These results might indicate that the increased production is the result of an increase in the supply of acetyl-CoA from glucose, since the metabolic flow of pyruvate to acetyl-CoA increases, compared to the flow to oxalacetate due to the decrease in pyruvate carboxylase.

It is generally known that the mitochondrial membrane is non-permeable to acetyl-CoA, and extramitochondial acetyl-CoA is formed through the action of a citrate cleavage enzyme (ATP citrate (pro-3S)-lyase) from citrate, for which the metochondrial membrane is permeable. ${ }^{9)}$ Glutamate auxotroph G-78 showed low citrate synthase activity and did not produce MPA, but did produce acetic acid. Therefore, it is reasonable to speculate that only extra-mitochondrial acetyl-CoA is used for MPA biosynthesis and that the increased amount of mitochondrial acetyl-CoA due to the defect in citrate synthase is hydrolyzed to acetic acid (and CoA), which is, then, accumulated extracellularly, as shown in this study.

Acknowledgment. The authors are indebted to Dr. H. Okada and Dr. R. Tsugawa of the Central Research Laboratories for their encouragement during this work.

\section{REFERENCES}

1) W. L. Muth and C. H. Nash, III, Antimicrob. Agents 
Chemother., 8, 321 (1975).

2) A. J. Birch, J. Agric. Food Chem., 19, 1088 (1971).

3) S. W. Queener, S. G. Wilkerson and C. H. Nash, "Overproduction of Microbial Products," ed. by V. Krumphabzl, B. Sikyta and Z. Vanek, Academic Press Inc., 1982, p. 535.

4) H. Ozaki, K. Kubota and H. Takahashi, Agric. Biol. Chem., 51, 2503 (1987).

5) M. C. Scrutton, M. R. Olmsted and M. F. Utter, "Methods in Enzymologly," Vol. XIII, ed. by S. P.
Colowick and N. O. Kaplan, Academic Press Inc., New York, 1969, p. 235.

6) P. A. Srere, H. Brazil and L. Gonen, Acta Chem. Scand., 17, S129 (1963).

7) D. R. Avoy, J. Lipid Res., 6, 369 (1965).

8) S. Omura, Bacteriol. Rev., 40, 681 (1976).

9) M. D. Lane and J. Moss, "Metabolic Pathways," Vol. V, ed. by H. J. Vogel, Academic Press Inc., 1971, p. 23. 